\title{
Comparative efficiency of three bait types for live trapping of small rodents in Central Africa
}

\author{
Jean-François MBOUMBA ${ }^{1,2^{\star}}$, Maxime R. HERVÉ ${ }^{3}$, Katy MORGAN ${ }^{4}$, Timy TIONGA ${ }^{1}$, Alyssa \\ TAYLOR $^{5}$, Natasha LOWERY ${ }^{6}$, Fabrice Mezeme NDONG ${ }^{1}$, Anicet Christel Maloupazoa \\ SIAWAYA ${ }^{1}$, and Nicola M. ANTHONY ${ }^{4}$ \\ ${ }^{1}$ Département de Biologie, Université des Sciences et Techniques de Masuku (USTM), Franceville B.P. 901, Gabon. \\ ${ }^{2}$ EA 7462 GTUBE, Université de Rennes 1, 35042 Rennes cedex, France. \\ ${ }^{3}$ IGEPP, Université de Rennes 1, Avenue du Général Leclerc 35042 Rennes, France. \\ ${ }^{4}$ Department of Biological Sciences, University of New Orleans, New Orleans, Louisiana 70148, USA. \\ ${ }^{5}$ University of California-Riverside UCCE - Riverside County, 21150 Box Springs Rd, Suite 202, Moreno Valley, CA, \\ 92557-8718, USA. \\ ${ }^{6}$ Tulane University, 6823 St. Charles Avenue, New Orleans LA 70118, USA.
}

Received 11 November, 2018; Accepted 13 February, 2019

Low capture rates are a persistent problem in field studies of small rodents in Central Africa. This study aims to improve trapping efficacy by comparing the effectiveness of three types of bait placed in Sherman live traps: the traditionally used fresh manioc, palm nut and bait composed of peanut butter mixed with corn flakes. Trapping sites were located in the buffer zones of a total of five forest national parks in Gabon and Cameroon. Traps lines were placed in a variety of forest and savanna habitats and were alternately baited with the three different bait types. Statistical analyses were performed using the $R$ software. A total of 212 individuals were trapped (during 3000 trap/night) from five species: Nannomys minutoides, Lemniscomys striatus, Hylomyscus alleni, Hylomyscus walterverheyeni and Praomys misonnei. Traps baited with peanut butter-corn flakes (PbCf) captured significantly more rodents $(n=125$, Trap success Ts $=12.25 \%)$ than either manioc $(n=31, T s=3.23 \% ; P<0.001)$ or palm nut $(n=56$, Ts $=5.49 \% ; P<0.001$ ) for four of the five species. This finding was consistent across all sampled habitats and for both sexes. Taken together, these findings strongly indicate that baiting with $\mathrm{PbCf}$ is likely to enhance the effectiveness of studies of small rodent fauna in Central Africa.

Key words: Bait, Muridae, Sherman traps, Gabon, Cameroon, field sampling.

\section{INTRODUCTION}

Low capture success $(<5 \%$ capture per trap night) remains a major problem for small rodent field surveys in Central Africa (CA), particularly in forested habitats
(Nicolas and Colyn, 2003; O'Brien et al., 2006). Manioc root (Manihot esculenta) and palm nuts (Elaeis guineensis) are commonly used as bait for live trapping

*Corresponding author. E-mail: mboumbafr@yahoo.fr. Tel: +24107041098.

Author(s) agree that this article remain permanently open access under the terms of the Creative Commons Attribution License 4.0 International License 


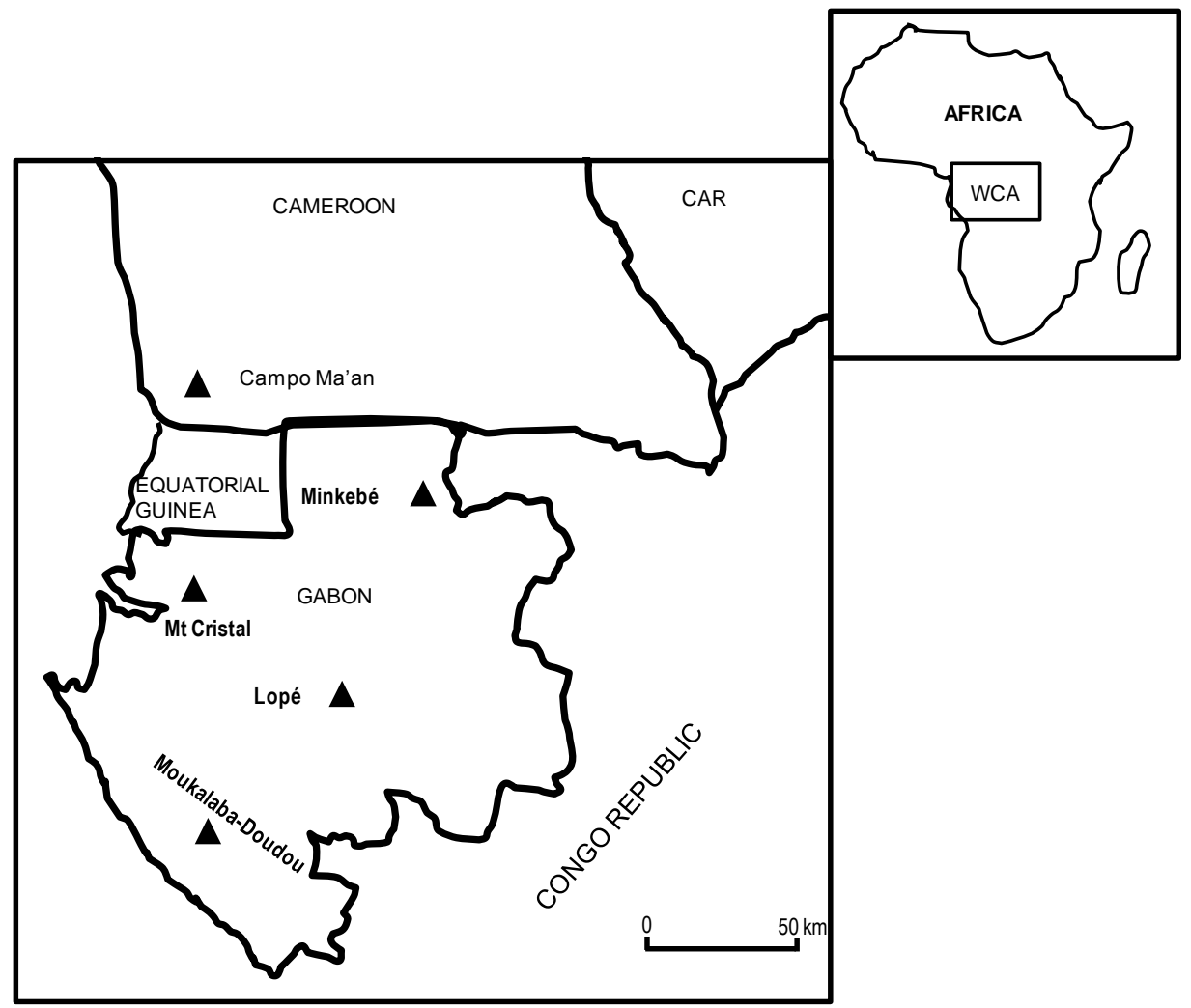

Figure 1. Map of Central Africa showing the sampling localities in Gabon and Cameroon. Localities are indicated by triangles: Lopé (forest-savanna mosaic: $00^{\circ} 07^{\prime} \mathrm{S}, 011^{\circ} 42.3^{\prime} \mathrm{E}$ ); Moukalaba-Doudou (coastal forest: $03^{\circ} 04.979$ ' S, $10^{\circ} 26.002^{\prime} \mathrm{E}$ ), Minkébé (lowland swamp forest: $01^{\circ} 09.436^{\prime} \mathrm{N}, 12^{\circ} 41.849^{\prime} \mathrm{E}$ ); Monts de Cristal (upland forest: $00^{\circ} 51.613^{\prime} \mathrm{N}$, $10^{\circ} 31.744^{\prime} \mathrm{E}$ ) and Campo-Ma'an (coastal forest: $\left.02^{\circ} 20.52^{\prime} \mathrm{N}, 10^{\circ} 12.634^{\prime} \mathrm{E}\right)$.

(Duplantier et al., 1984; Duplantier, 1989; Nicolas and Colyn, 2003; Amundala et al., 2014; Katuala et al., 2005, 2008; Nicolas and Colyn, 2006; O'Brien et al., 2006; Nicolas and Colyn, 2007; lyongo et al., 2012; 2013) but their efficiency is low, prompting researchers to look for more attractive types of bait.

Although peanut butter has been used in several previous rodent surveys across the region, its efficacy relative to other traditional bait types has not been systematically compared. Bâ et al. (2012) used peanut butter as bait with a relatively high trap success (Ts) of $12.8 \%$. Similarly, Webala et al. (2006) obtained a $T_{S}$ of $7.25 \%$ using a mixture of peanut butter, 'maize meal', fried coconut and mashed ripe bananas, while Kok et al. (2013) obtained a Ts of $11.7 \%$ using a mix of oats and peanut butter. However, in another study by O'Brien et al. (2006), peanut butter mixed with oats yielded a relatively low trap success $(T s=0.4 \%)$. The disparity between these results and the absence of a standardized experimental design for comparing bait types prompted us to explicitly test the efficiency of a mixture of peanut butter and corn flakes (PbCf) relative to manioc and palm nut in order to establish whether a more efficient sampling strategy could be used in future surveys.

\section{MATERIALS AND METHODS}

\section{Study sites}

This study was carried out in the buffer zones of four National parks (NPs) in Gabon and one NP in Cameroon. These sites comprise: Lopé NP (Central Gabon, 0007' S, 011 42.3' E), MoukalabaDoudou NP (Southwestern Gabon, 0304.979' S, 10²6.002' E), Minkébé NP (Northwestern Gabon, $01^{\circ} 09.436^{\prime} \mathrm{N}, 12^{\circ} 41.849^{\prime} \mathrm{E}$ ), Mont de Cristal NP (Northwest Gabon, 0051.613' N, 10³1.744' E) and Campo-Ma'an NP (Southwestern Cameroon,02 $20.52^{\prime} \mathrm{N}$, $\left.10^{\circ} 12.634^{\prime} \mathrm{E}\right)$. These sites encompass a range of lowland rainforest types including coastal forest (Moukalaba-Doudou, Campo Ma'an), forest-savanna mosaic (Lopé), upland forest (Mont de Cristal) and lowland swamp forest (Minkébé) (Figure 1). At Lopé, three out of four trap lines were placed in savanna habitat.

\section{Small rodent sampling strategy}

All rodent live trapping was carried out using Sherman live traps 
Table 1. Number of captures of each species by bait type and in each habitat type.

\begin{tabular}{lcccccccl}
\hline \multirow{2}{*}{ Species } & $\begin{array}{c}\text { Peanut butter corn } \\
\text { flakes }\left(\mathbf{N}_{\mathrm{TN}}=\mathbf{1 0 2 0}\right)\end{array}$ & \multicolumn{2}{c}{$\begin{array}{c}\text { Manioc } \\
\left(\mathbf{N}_{\mathrm{TN}}=\mathbf{9 6 0}\right)\end{array}$} & \multicolumn{2}{c}{$\begin{array}{c}\text { Palm nut } \\
\left(\mathbf{N}_{\mathrm{TN}}=\mathbf{1 0 2 0}\right)\end{array}$} & Habitat type \\
\cline { 2 - 10 } & $\mathbf{n}$ & $\mathbf{T s}(\%)$ & $\mathbf{n}$ & $\mathbf{T s}(\%)$ & $\mathbf{n}$ & $\mathbf{T s}(\%)$ & Total & \\
\hline Lemniscomys striatus & 6 & 0.6 & 1 & 0.1 & 2 & 0.2 & 9 & LOS \\
Nannomys minutoides & 35 & 3.43 & 19 & 1.98 & 14 & 1.4 & 68 & LOS \\
Hylomyscus alleni & 6 & 0.6 & 0 & 0 & 4 & 0.3 & 10 & MCF, MKF \\
Hylomyscus walterverheyeni & 9 & 0.88 & 0 & 0 & 11 & 1.5 & 20 & MD \\
Praomys misonnei & 69 & 6.76 & 11 & 1.15 & 25 & 2.56 & 105 & CMF, MD, LOF, MCF, MKF \\
Total $\left(\mathrm{N}_{\mathrm{m}}\right)$ & 125 & $\mathbf{1 2 . 2 5}$ & 31 & $\mathbf{3 . 2 3}$ & 56 & $\mathbf{5 . 4 9}$ & 212 & \\
\hline
\end{tabular}

$\mathrm{N}$, number of individuals; Ts, trap success $=\left[\left(\mathrm{N}_{\mathrm{m}} / \mathrm{N}_{\mathrm{TN}}\right) \times 100\right]$ where $\mathrm{N}_{\mathrm{m}}$ is the number of mice trapped, $\mathrm{N}_{\mathrm{TN}}$ is the number of trap-nights; MCF, Mont de Cristal Forest (National Park); MKF, Minkebé Forest (National Park); MD, Moukalaba-Doudou (National Park ); CMF, Camp Ma'an Forest (National Park); LOF, Lopé Forest (National Park); LOS, Lopé savanna (National Park).

$(7.5 \times 9 \times 23 \mathrm{~cm})$. At each site, four trap lines of $250 \mathrm{~m}$ in length were laid out at a distance of at least $25 \mathrm{~m}$ apart. Each trap line was made up of 50 Sherman live traps $(7.5 \times 9 \times 23 \mathrm{~cm})$ placed at regular intervals of $5 \mathrm{~m}$ along the length of each transect (Gautun et al., 1986; Nicolas and Colyn, 2003; Fichet-Calvet et al., 2009; Nicolas et al., 2010a; Denys et al., 2014). Traps were baited in equal proportions with either manioc, palm nut or PbCf. Trapping was conducted for a maximum of five consecutive nights at each site.

Traps were checked two times per day in the early morning and late afternoon and fresh bait was applied when necessary. At each site, up to 30 captured individuals were euthanized by cervical dislocation, measured, weighed and sexed for species identification and tissue samples were stored in ethanol 96\% until DNA extraction. Any additional specimens were identified and released at their point of capture. All animal handling and processing was carried out according to UNO IACUC protocol 12-008.

\section{Species identification}

In order to avoid misidentification of specimens within the morphologically similar species complexes within the genera Hylomyscus and Praomys, species were identified based on external morphology (Kingdon, 2003; Musser and Carleton, 2005; Happold, 2013); and sequencing mitochondrial genes 16S rRNA and cytochrome $b$ gene sequences were employed to clarify identifications where external morphology was ambiguous (Nicolas and Colyn, 2003; Nicolas et al., 2010b; Mboumba et al., 2011).

\section{Statistical analysis}

Trap success $(T s)=\left[\left(\mathrm{N}_{\mathrm{m}} / \mathrm{N}_{\mathrm{TN}}\right) \times 100\right]$ was estimated at each site; where $\mathrm{N}_{\mathrm{m}}$ is the total number of individuals and $\mathrm{N}_{T N}$ is the number of trap-nights (Nicolas and Colyn, 2003; Kadjo et al., 2013). Ts was compared among bait types using a chi-squared test, and $P$-values for all pairwise comparisons were adjusted using the False Discovery Rate correction (FDR; Benjamini and Hochberg, 1995). The number of individuals trapped by bait type was also analyzed separately for each species using an exact multinomial test. Pairwise comparisons between bait types were performed using exact binomial tests with FDR-corrected $P$-values. Statistical analyses were performed using the $\mathrm{R}$ software ( $\mathrm{R}$ Core Team, 2014).

\section{RESULTS}

A total of seven species of rodents were captured all at night. These comprise: Hylomyscus alleni, $H$. walterverheyeni, Praomys misonnei, Nannomys minutoides, Lemniscomys striatus, Heimyscus fumosus and an unidentified Praomys sp. The latter two species were not trapped in sufficient numbers to allow for statistical analyses.

\section{Global trapping effectiveness per type of bait}

All seven species were trapped with $\mathrm{PbCf}$; whereas only five species were captured with palm nut and four with manioc (Table 1). Two species ( $N$. minutoides and $L$. striatus) were trapped exclusively in savanna habitat while the remaining species were restricted to forest habitats. The overall Ts for all species was $7.1 \%$ across all localities and varied significantly according to bait type $\left(X^{2}=67.19, \mathrm{df}=2, P<0.001\right)$. Across all species and all localities $\mathrm{PbCf}$ was the most efficient bait (Ts $=12.25 \%$ ), capturing significantly more rodents than either manioc (Ts $\left.=3.23 \%, X^{2}=54.27, \mathrm{df}=1, P<0.001\right)$ or palm nut (Ts $\left.=5.49 \%, X^{2}=28.03 \mathrm{df}=1, P<0.001\right)$. Of the two least attractive baits, palm nut attracted significantly more rodents than manioc $\left(5.49 \%\right.$ vs. $3.23 \%, X^{2}=5.49$, df $=1$, $P=0.019$; Table 1).

The global trap success observed in the present study was comparable to levels of success obtained in West African savannas by Bâ et al. (2012; Ts $=12 \%)$ and South African montane savannas (Kok et al., 2013; Ts = approx. $12.8 \%$ ), and superior to capture rates in the Ivory Coast (Traoré et al., 1980; Ts = 1.7\% - 2.43\%)

\section{Bait effectiveness by species}

Within species, $\mathrm{PbCf}$ was the most attractive bait type for four of the five most commonly encountered species: $H$. 

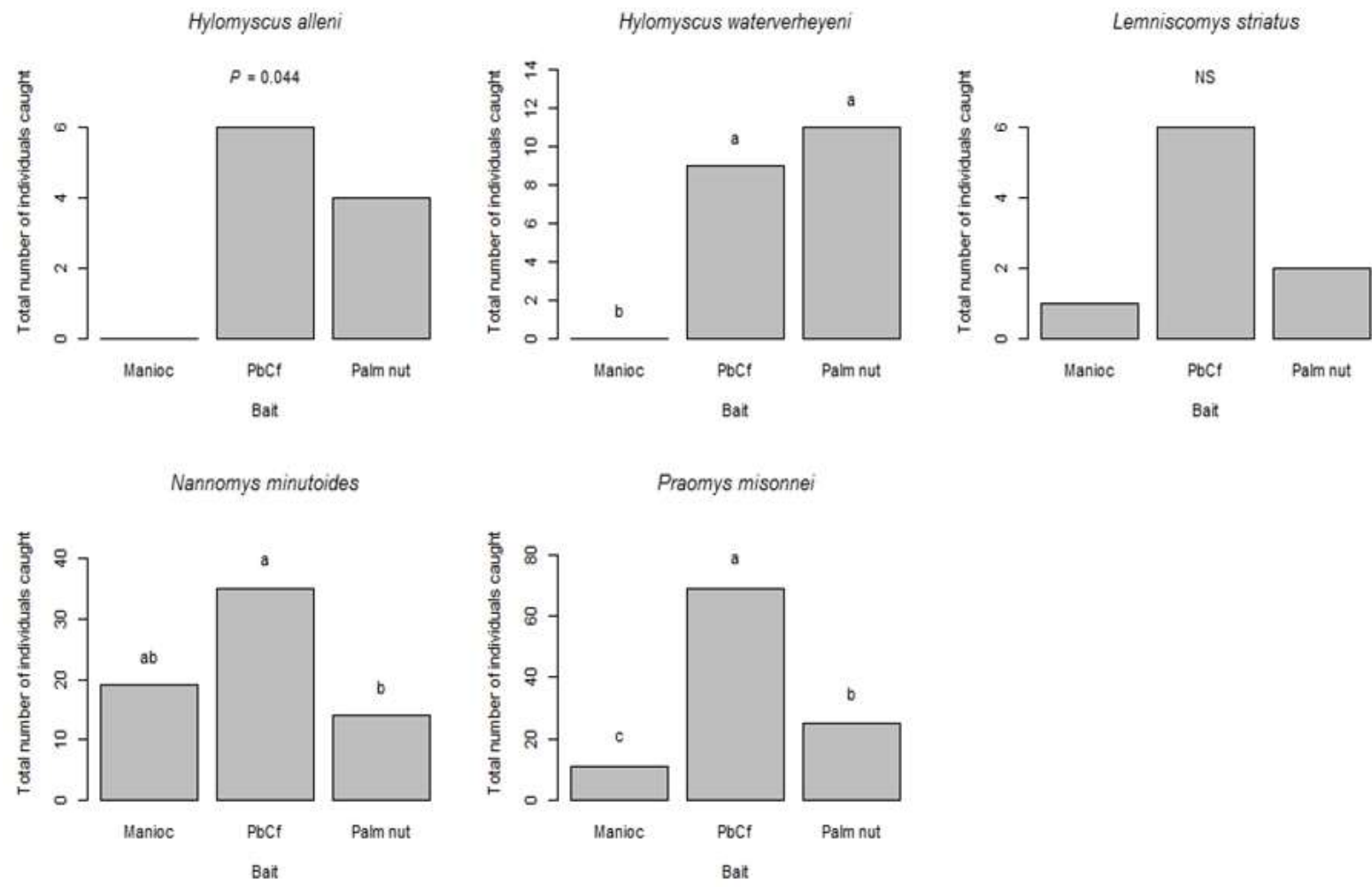

Figure 2. Total number of individuals captured per bait type, for each rodent species. Different letters indicate significantly different counts.

walterverheyeni, $P=0.001 ; N$. minutoides, $P=0.006 ; P$. misonnei, $P<0.001 ; H$. alleni, $P=0.044$ (Figure 2). $L$. striatus was the only species that showed no significant preference in bait type $(P=0.166)$ (Figure 2).

\section{DISCUSSION}

Overall, our results show that $\mathrm{PbCf}$ bait is generally more effective than either palm nut or manioc. The global trap success with $\mathrm{PbCf}$ was far higher than that of previous studies in Central Africa using Sherman traps baited with either manioc or palm nut (Nicolas and Colyn, 2003). In particular, the $T_{S}$ for rodents caught in MoukalabaDoudou National Park using PbCf was far better than the $0.4 \%$ obtained at the same site by O'Brien et al. (2006). Both studies used the same trap type but in the case of O'Brien et al. (2006) were baited with peanut butter and oats instead of peanut butter and corn flakes, which could be one of the factors explaining these differences in Ts.

Palm nuts had been used routinely in field sampling studies in CA because they are a local native forest product, easily available and inexpensive. Similarly, manioc is also readily available locally and is regularly cultivated in fields in savannas and forest clearings.
However, palm nuts are only effective when fresh and decay rapidly after being harvested, posing a serious problem for long-term field sampling missions away from villages. Also, their fruiting period is seasonal, limiting their availability at certain times of the year. In contrast, $\mathrm{PbCf}$ is available at all times of the year, is nonperishable and has been shown here to be extremely effective relative to both local bait types. We therefore recommend using $\mathrm{PbCf}$ bait routinely as bait in field sampling studies of small rodents in CA since the cost of purchasing these products will rapidly be outweighed by the greater capture success.

\section{Conclusion}

This study shows that PbCf is a more effective at capturing small rodents than other more traditional baits. Specifically, the number of individuals and species captured was greater using $\mathrm{PbCf}$ than either manioc or palm nut. We therefore recommend its use in studies of small mammal biodiversity in the central African tropics as it both saves time and improves capture success, thus overcoming two, major constraints in studies of small rodent populations. 


\section{CONFLICT OF INTERESTS}

The authors declare that they have no conflict of interests.

\section{ACKNOWLEDGEMENTS}

This study was funded by the National Science Foundation OISE 1243524 and the Université des Sciences et Techniques de Masuku. We would like to thank Elise Mayzerac of the Wildlife Conservation Society (WCS-Gabon) and the park manager (Benoit Nziengui) of Lopé National Park for their logistical support and advice. We would also like to thank the Centre National de la Recherche Scientifique (CENAREST) in Gabon for permission to conduct this study and the Agence National des Parcs Nationaux (ANPN) for permission to conduct research within the buffer zone of four national parks in Gabon. We would also like to thank the Ministère des Eaux et Forets (MINEF) and the Ministère de la Recherche Scientifique et Technique et de l'Innovation (MINRESI) for permission to conduct work in Cameroon. We thank Pierre Deleporte for helpful suggestions during the writing of this note.

\section{REFERENCES}

Amundala D, Bapeamoni A, Lyongo W, Kennis J, Gambalemoke M, Kadange N, Katuala PGB, Denys C, Missoup AD, Nicolas V, Fülling O, Delapré A, Bilong Bilong CF, Taylor PJJ, Hutterer R (2014). African highlands as mammal diversity hotspots: new records of Lamottemys okuensis Petter, 1986 (Rodentia: Muridae) and other endemic rodents from Mt Oku, Cameroon. Zoosystema 36(3):647-690.

Bâ K, Kane M, Gauthier P, Granjon L (2012). Ecology of a typical West African Sudanian savanna rodent community. African Journal of Ecology 51:447-455.

Benjamini Y, Hochberg Y (1995). Controlling the false discovery rate: a practical and powerful approach to multiple testing. Journal of Royal Statistical Society. Series B 57:289-300.

Duplantier JM, Orsini P, Thohari M, Cassing J, Croset H (1984). Echantillonnage des populations des Muridés : influence du protocole de piégeage sur l'estimation des parameters démographiques. Mammalia 48(1):129-141.

Duplantier JM (1989). Les rongeurs Myomorphes Forestiers du Nord.Est du Gabon: Structure du peuplement, démographie, domaines vitaux. Revue d'Ecologie (Terre Vie) 44:329-346.

Fichet-Calvet $E$, Lecompte $E$, Veyrunes $F$, Barrière $P$, Nicolas $V$, Koulémou K (2009). Diversity and dynamics in a community of small mammals in coastal Guinea, West Africa. Belgian Journal of Zoology 139(2):93-102.

Gautun JC, Sankhon I, Tranier M (1986). Nouvelle contribution à la connaissance de rongeurs du massif guinéen des monts Nimba (Afrique occidentale). Systématique et aperç̧u quantitatif. Mammalia, tome50, $\mathrm{n}^{\circ} 2$.

Happold DCD (2013). Rodents, hares and rabbits. In: Kingdon J, Happold DCD, Hoffmann M, Butynski T, Happold M, Kalina J (Eds.), Mammals of Africa. London: Bloomsbury Publishing. pp. 912-1696.

lyongo WML, Visser M, Cannière C. De, Verheyen E, Dudu BA, Ulyel J, Patho A, Bogaert J (2012). Anthropisation et effet de lisière : impacts sur la diversité des rongeurs dans la Réserve forestière de Masako (Kisangani, R.D. Congo). Tropical conservation Science 5(3):270283. lyongo Waya Mongo L, De Cannière C, Ulyel J, Dudu BA, Bukasa K, Verheyen E, Bogaert J (2013). Effets de lisière et sex-ratio de rongeurs forestiers dans un écosystème fragmenté en République Démocratique du Congo (Réserve de Masako, Kisangani). Tropicultura 31(1):3-9.

Kadjo B, Kouadio RY, Vogel V, Dubey S, Vogel P (2013). Assessment of terrestrial smallmammals and record of critically endengered shrew Crocidura wimmeri in BancoNational Park (Cote d'Ivoire). Mammalia 77(4):439-446.

Katuala PGB, Kennis J, Nicolas V, Wendelen W, Hulselmans J, Verheyen E, Van Houtte N, Dierckx T, Dudu AM, Leirs H (2008). The presence of Praomys, Lophuromys and Daomys species (Muridae, Mammalia) in the blocks separated by the Congo River and its tributarie (Kisangani region, Democratic Republic of Congo). Mammalia 72:223-228.

Katuala PGB, Hart JA, Hutterer R, Leirs H, Dudu A (2005). Biodiversity and ecology of small mammals (Rodents and Shrews) of the "Réserve de Faune à Okapis", Démocratic Republic of Congo. Belgian Journal of Zoology 135(Supplement):191-196.

Kingdon J (2003). Field Guide to African Mammals. A\&B Black Publishers Ltd., London. pp. 159-214.

Kok AD, Parker DM, Barker NP (2013). Rules of attraction: the role of bait in small mammal sampling at high altitude in South Africa. African Zoology 48:84-95.

Musser GG, Carleton MD (2005). Family Muridae. Mammal species of the world: a taxonomic and geographic reference, Third Edition (ed. By Wilson DE and Reeder DM). Smithsonian Institution Press. pp. 1387-1398.

Mboumba JF, Deleporte P, Colyn M, Nicolas V (2011). Phylogeography of Mus (Nannomys) minutoides (Rodentia, Muridae) in West Central African savannahs: Singular vicariance in neighbouring populations. Journal of Zoologycal Systematics Evolution Research 49:77-85.

Nicolas V, Colyn M (2003). Seasonal variations in population and community structure of small rodents in a tropical forest of Gabon. Canadian Journal of Zoology 81:1034-1046.

Nicolas V, Colyn M (2006). Relative efficiency of three types of small mammal traps in an African rainforest. Belgian Journal of Zoology 136:107-112.

Nicolas V, Colyn M (2007). Efficiency of fluorescent powder tracking for studying use of space by small mammals in an African rainforest. African Journal of Ecology 45:577-580.

Nicolas V, Natta A, Barrière P, Delapre A, Colyn M (2010a). Terrestrial small mammal diversity and abundance in central Benin: comparison between habitats, with conservation implications. African Journal of Ecology 48:1092-1104.

Nicolas V, Oloyemi A, Wendelen W, Colyn M (2010b). Mitochondrial DNA and morphometrical identification of a new species of Hylomyscus (Rodentia: Muridae) from West Africa. Zootaxa 2579:3044.

O'Brien C, McShea W, Guimondou S, Barrière P, Carleton M (2006). Petits mammifères terrestres (Soricidés et Muridés) du Complexe d'Aires Protégées de Gamba, Gabon: composition taxinomique et comparaison de méthodes d'échantillonnage. Bulletin Biological Society of Washington 12:137-148.

R Core T (2014). R: A language and environment for statistical computing. R Foundation for Statistical Computing, Vienna, Austria. Available at: http://www.R-project.org

Traoré K, Gautun JC, Diomande M (1980). Comparaison des peuplements de Rongeurs Muridés dans trois savanes de Côte d'Ivoire (savanes prélagunaire de Dabou, préforestière à Rôniers de Lamto et guinéenne arbustive du Foro). Annales, Université Abidjan, Série $\mathrm{E}$ (écologique), Tome XIII.

Webala PW, Muriuki G, Lala F, Bett A (2006). The small mammal community of Mukogodo Forest, Kenya. African Journal of Ecology 44:363-370. 